\title{
RECONSTRUCTION OF PRINCIPLES OF LEGALITY IN CRIMINAL LAW BASED ON JUSTICE VALUE OF PANCASILA
}

\author{
Muhammad Yahya Selma \\ Lecturer in Faculty of Law \\ Muhammadiyah University Palembang South Sumatera \\ E-mail : muhammadyselma@gmail.com
}

\begin{abstract}
Amendment of the Constitution 1945 after the fourth amendment, reinforce the concept of the state law and put it in Article 1 paragraph 3 of the Constitution of the Republic of Indonesia in 1945 which reads : "The State of Indonesia is a state of law". The enactment of the provisions of Article 1 Paragraph (3) the Constitution of the Republic of Indonesia in 1945 brought a fundamental change to the principle of legality, which was previously law in Indonesia based on written law only, being based on written law and unwritten law or law that lives and grows in society. Law in Indonesia is based on the value of justice living in society based on the values of Pancasila.
\end{abstract}

Keyword : Principles of Legality, Criminal Law, and Pancasila Justice

\section{A. INTRODUCTION}

Humans desperately need the law as a set of rules of social life that are agreed and obeyed together. The law can not be separated from its obligation to change in order to follow the development of human civilization. Unfortunately the development of law is always left behind from the development of human perempt itself ${ }^{1}$ however, at least the law will always follow the changes that take place in society (except the permanent law established by Allah S.W.T will never change except by His permission).

Law as a system, namely the substance of law, the structure of law and the culture of law, ${ }^{2}$ often can not entirely follow the changes of society, especially since the phenomenal period of reform in Indonesia.

As revealed by Satjipto Rahardjo that the law is not in a vacuum or a vacuum, but it is in society ". Furthermore he said that the law in relation to the sense of community justice, the law is considered as a means of channeling for all the difficulties faced by society. The law must

\footnotetext{
Satjipto Rahardjo, Hukum dan Perubahan Sosial, Alumni, Bandung, 1979, page 72.

2 Lawrence M. Friedman, in Satjipto Rahardjo, The Legal System: A Social Science Perspective, Russell Sage Foundation, New York, 1989, p. 10. See also Lawrence M. Friedman, Legal Culture and Welfare State, Walfer de Gruyter, page 17.
}

come down into society to become a savior of society's difficulties, the law should not be a mere ivory tower or side with a particular group ". 3

The amendment of the 1945 Constitution especially after the fourth amendment reinforces the concept of a state law and puts it in Article 1 paragraph (3) of the 1945 Constitution of the Republic of Indonesia reads: "The State of Indonesia is a state of law". State law in question is a country that puts the law as commander in regulating the life of Indonesian society.

Referring to the concept of the legal state put forward by M.C. Burkens, there are four elements of the legal state (rechtsstaat), namely the principle of legality, power sharing, basic rights (grondrechten) is the objective of government protection against the people and at the same time limits the power of legislators, as well as court supervision for the people available channels through free trials to test the legitimacy of government action "rechtmatigeheidstoetsing". ${ }^{4}$

In connection with the change of the concept of a legal state as embodied in the provision of Article 1 Paragraph (3) of the 1945 Constitution of

\footnotetext{
3 Satjipto Rahardjo, Democracy Need Progressive Legal Support, Kompas, Jakarta, 2004, page 11

4 M.C. Burkens quoted John Usfunan, Freedom of Opinion in Indonesia, (Dissertation), Graduated with a Doctorate at UNAIR Postgraduate Program, Surabaya, 1998, page 19
} 
the Republic of Indonesia, there is an interesting issue for a deeper review, especially concerning the changing of the concept of a legal state as contained in the Elucidation of the 1945 Constitution amendment, namely: "The state of Indonesia is based on law (rechtsstaat), not based on mere power (machtstaat)". While the provisions in Article 1 paragraph (3) of the 1945 Constitution of the fourth amendment, which reads: "The State of Indonesia is a state of law".

The application of the legality principle adopted in Indonesia is no longer an absolute character, as it implicitly recognizes other than written law (law) as well as the recognition of the unwritten law in society. If seeking the constitutional basis of the principle of legality in the 1945 Constitution of $\mathrm{NRI}$ as Article 1 paragraph (3) that: "the State of Indonesia is a state of law" there is no framework of the concept of legal state rechtsstaat or the concept of rule of law law that we use, it means that in the absence of frills the word rechtsstaat is a thing done intentionally, with the aim of giving a wide place on the fulfillment of sense of justice (the rule of law). This means that for the sake of justice, it should be an unfair, dishonorable or inappropriate behavior in society so that it can be formally punished, but there is no written law that prohibits it. ${ }^{5}$ So, how does the change in the concept of Indonesian legal state as defined by Article 1 paragraph (3) of the 1945 Constitution after the amendment. And what are the implications of such changes to the legality principle in the Indonesian criminal law system. And how does the reconstruction of the principle of legality in criminal law based on Pancasila justice value.

\section{B. DISCUSSION}

1. Changes in the concept of an Indonesian legal state as stipulated in Article 1 paragraph (3) of the 1945 Constitution after the amendment;

Provisions on the rule of law are further substantiated in the Constitution after the

\footnotetext{
5 Moh. Mahfud MD, Legal Politics Toward the Development of the National Legal System, Seminar Paper: "The Direction of Legal Development According to the 1945 Amendment Result", BPHN, Jakarta 29-31 May 2006, page 1-2. See also Moh. Mahfud MD, Building a Political Law Upholding the Constitution, Library LP3ES, Jakarta, 2006, page 13-16.
}

amendment. This can be proven in the provisions of Article 1 Paragraph (3), Article 24, Article 28H Paragraph (2), Article 28I Paragraph (1) and Paragraph (5), Article 28J of the 1945 Constitution of 1945. Provisions on the State of Law in Article 1 Paragraph 3) of the 1945 Constitution of the Republic of Indonesia, where previously only stipulated in the section on the 1945 Constitution before the amendment, was basically not accompanied by a further explanation of the meaning of the state law itself.

In Indonesia, before the 1945 Constitution was amended, the conception of a legal state adopted was rechtsstaat and after the third amendment adopted on 10 November 2001, the term rechtsstaat was no longer listed, but only mentioned, "The State of Indonesia is a state of law". Theoretically, the conception of the legal state embraced by Indonesia is not from a formal dimension, but in a material sense or commonly used in the terminology of the welfare state or welfare state. Therefore, the goal to be achieved by the state of Indonesia is the realization of a just and prosperous society both spiritual and material based on Pancasila, so it is also called a legal state that has independent characteristics, namely the State of Law based on Pancasila. ${ }^{6}$

In relation to changes in the concept of a legal state as stipulated under Article 1 paragraph (3) of the 1945 Constitution of the Republic of Indonesia, Rukmana Amanwinata ${ }^{7}$ argued that in Indonesia, before the 1945 Constitution was amended, the conception of a legal state adopted was rechtsstaat and after the third amendment adopted on November 10, 2001, the term rechtsstaat

6 Results of interview with Sri Suatmiati, Lecturer of Constitutional Law Faculty of Law Muhammadiyah University of Palembang, on June 16, 2015.

7 Rukmana Amanwinata, Arrangements and Limits of Independence and Associated Implementation in Article 28 of the 1945 Constitution, Dissertation, Postgraduate Faculty of Padjadjaran University, Bandung, 1996, p. 109, in Ninil Eva Yustina, Acts Against Material Law (Materiel Wederrechtelijkeheid) In Criminal Acts of Corruption in Indonesian Judicial Practice Post Constitutional Court Ruling, Article (Summary of Thesis on Graduate Law Program of Criminal Law Concentration Universitas Merdeka Malang, February 21, 2009, See Article 
was no longer listed, but merely mentioned, "Indonesia is a state of law". Theoretically, the conception of the legal state embraced by Indonesia is not from a formal dimension, but in a material sense or commonly used in the terminology of the welfare state or welfare state. Therefore, the goal to be achieved by the state of Indonesia is the realization of a just and prosperous society both spiritual and material based on Pancasila, so it is also called a legal state that has independent characteristics, namely the legal state based on Pancasila. ${ }^{8}$

With the removal of the term "rechtsstaat" in Article 1 number (3) of the 1945 Constitution of the Republic of Indonesia, it affirms that the conception of a legal state embraced by Indonesia is a legal concept of a material or a concept of a legal state in a broad sense, legal certainty but more prioritize the legal certainty to obtain justice which at the same time opens the opportunity to apply in the court (criminal) of unwritten law or living law. ${ }^{9}$

Further Moh. Mahfud MD, said that by neutralizing him as a state of law that once seemed to embrace rechtsstaat, our legal politics about the conception of the law state embraces the good elements of rechtsstaat and the rule of law, even other legal systems at once. In the past, the concept of a state law was affirmed in the Elucidation of the Constitution with the phrase "Indonesia is a state based on law (rechtsstaat) ...", but now the Elucidation of the Constitution has been invalid and the statutes of the constitutional state are cast into the constitution transferred into Article 1 paragraph (3) with a neutral sentence, that is, "the State of Indonesia is a state of law". 10

Indeed, it must be admitted that the affirmation of the Indonesian law state according to the 1945 Constitution of the Republic of Indonesia does not have to be seen as a final building, but a building that

\footnotetext{
8 See Article 3 of the amended 1945 Constitution (the third amendment, adopted November 10, 2001).

9 Moh. Mahfud MD, Constitutional Law Debate Post Constitution Amendment, Raja Grafindo Persada, Jakarta, 2010, page 52.

10 lbid.
}

must constantly be addressed to achieve the real Indonesia. For example, consider the extent to which harmonization of customary law and national law relations in the process of developing an Indonesian law state. ${ }^{11}$

We all must recognize that the ideals of Indonesian law are derived from Pancasila which is a philosophical-gronslag and common platform as the basis of the state. Therefore, the activities of law-making institutions should be voiced on the common platform values that are full of culture, values that live in the community or local wisdom attached to them. Even in the legal system of Pancasila, the established state of law must be able to harmoniously integrate elements of rechtsstaat (legal certainty) and the rule of law (substantial justice). ${ }^{12}$

The regulation on the state law in the 1945 Constitution of the Republic of Indonesia is placed through Article 1 paragraph (3), which determines that the State of Indonesia is a state of law. There are at least two substantial understandable meanings of the transfer of this provision from those previously placed in the "Explanatory" section of the 1945 Constitution before the amendment, then placed in the "Articles" section of the 1945 Constitution of the Republic of Indonesia.

It can be concluded that the interpretation of the splits of the articles into the 1945 Constitution of the Republic of Indonesia relating to the concept of the legal state of Indonesia, namely:

The first is that the transfer of the provisions concerning the rule of law into the "Articles" section indicates an effort to affirm the concept of a legal state for Indonesia. With the transfer referred to in the "Articles" section, it is expected that the

\footnotetext{
11 Yanis Maladi, Existence of Indigenous Laws in the Post-Amendment State Constitution, Journal of the Mimbar Hukum, Vol. 22 No. 3, October 2010 Edition, Faculty of Law UGM, Yogyakarta, 2010, p. 458.

12 Wahyu Nugrono, Developing a Responsive and Participatory Law Based on the Idea of Pancasila Law, Journal of Indonesian Legislation, Vol. 10 No. 3, September 2013 Edition, Directorate General of Legislation and Regulation of the Ministry of Justice and Human Rights of the Republic of Indonesia, Jakarta, 2013, page 212 .
} 
binding power of the rule of law for Indonesia will be stronger. Second, the transfer can also be interpreted as an attempt to reaffirm that the Indonesian nation will seriously base all life activities of the nation and state on the existing legal provisions.

\section{Implications of such changes to the legality principle in the Indonesian criminal law system;}

The principle of legality as defined in the constitutional law of each country's constitution or constitution is one of the fundamental principles that must be maintained for the sake of legal certainty. The meaning of the principle of legality must be interpreted wisely in the framework of law enforcement and justice. When viewed from the situation and condition of the birth of legality, the principle is to protect the interests of the individual as the main characteristic of criminal law according to the classical school. The application of the principle of legality varies from country to country, depending on whether the system of government in the country is democratic or tyrannical. Variations also depend on the legal family it embraces.

According to Moeljatno, the principle of legality, the decisive principle, that "no action is prohibited and threatened with crime if not determined in advance in legislation". Usually this is known in Latin as nullum delictum nulla poena sine praevia lege (no offense, no criminal without rules first). ${ }^{13}$ According Wirjono Prodjodikoro, Latin which reads: nullumdelictum, nulla puna sine praevia lege punali, defined "no crime, no criminal penalty without penal law first". ${ }^{14}$

In the Criminal Code of the Year 2015 the provisions of Article 1 paragraph (1) reads: "No one shall be liable or subject to action, unless the acts committed have been established as a criminal act in the laws and regulations applicable at the time the act is committed" and Article 1 paragraph (2) is stipulated that "In determining the existence of a criminal

13 Moeljatno, Principles of Criminal Law, Bina Aksara, Jakarta, 1987, page 23.

14 Wirjono Prodjodikoro, Principles of Criminal Law In Indonesia, Refika Aditama, Bandung, 2003, page 43. offense is prohibited to use analogy". This means that the Indonesian criminal law is based on the legality principle reinforced by the prohibition of using analogy interpretation. ${ }^{15}$ Nevertheless, the principle of legality can be set aside by enacting living law.

In the 1945 Constitution the second amendment result, in the provisions of Article 18B paragraph (2) shall be regulated in a limitative manner, that: "The State recognizes and respects the units of indigenous and tribal peoples as long as they are alive and in accordance with the development of society and principles Unitary State of the Republic of Indonesia as governed by law ". Then this is reinforced also by the provision of Article 1 Paragraph (3) of the 1945 Constitution of 1945 of the third amendment which implies the recognition of the unwritten law in the legal sense living in the community.

The principle of material legality in its application in Indonesia has a legal basis, namely Article 5 paragraph (3) sub b Emergency Law no. 1 of 1951 and subsequently responded in Article 2 paragraph (1) of the 2015 Criminal Code which respects the laws that live in society. The principle of material legality indicates that before there is a written or written legislation or legislation, the unwritten law that lives in society, whereas in retroactive principle it emphasizes the application of written law which is applied to the act or crime which occurred before the written law came into being. In fact, in the concept of the principle of legality has shifted, not only determined formally (written law) but also determined materially (unwritten law). This is evidenced by the change of the concept of Indonesian legal state as set forth in Article 1 paragraph (3) of the 1945 Constitution of the Republic of Indonesia amendment results.

\footnotetext{
15 Interpretation of the analogy means to give an interpretation of a rule of law by giving (kiyas) to the words in accordance with its legal principle, so that a real event can not be entered, then considered in accordance with the sound of the rule. For example: "connect" the flow of electricity is considered the same as "take" the flow of electricity. http://rezarizkyfarza.blogspot.co.id/2013/05 / interpretation-hukum.html accessed November 14, 2015, at $4.52 \mathrm{pm}$.
} 
Based on the recognition of the formal and material legality principle, what is categorized as an offense is not only unlawful acts / contrary to the law, but must also be contrary to the unwritten law. In the case of the determination of a crime in Article 12 paragraph (2) of the Criminal Code of 2015 states that: "To be declared a crime of an act which is threatened by criminal law shall also be unlawful or contrary to living law in society ". After the enactment of the 1945 Constitution of the Republic of Indonesia (after the amendment) where there has been a change in the concept of an Indonesian legal state in which the implicit principle of legality is characterized by the occurrence of acknowledgment of the unwritten law (living law in society, that is religious law and law custom). Such conditions have implications for all sets of Indonesian laws under the 1945 Constitution of the State of the Republic of Indonesia whose position as the highest source of law after Pancasila as grundnorm. The implications of such changes also occur in all the provisions relating to the principle of legality in the laws and regulations of criminal law in Indonesia whose position under the 1945 Constitution of the Republic of Indonesia in accordance with the provisions of Article 7 of Law No. 12 of 2011 on the Establishment of Laws and Regulations, which implies : Article 5 paragraph (1) and Article 50 paragraph (1) of Law Number 48 Year 2009 regarding Judicial Power; Article 8 paragraph (4) of Law no. 16 of 2004 on the Attorney of the Republic of Indonesia; Article 1 paragraph (1) and paragraph (2) and Article 103 of the Criminal Code (WvS); Decision of the Constitutional Court No. : 013 / PUU-I / 2003 and No. : 003 / PUU-IV / 2006; and the National Criminal Laws of 2015. All official regulations as positive law concerning the legality principle in Indonesia must adapt and be guided by the legality principle in the legal state as stipulated in Article 1 paragraph (3) of the 1945 Constitution of the Republic of Indonesia.

\section{Reconstruction of legality principle in criminal law based on Pancasila justice value.}

As a result of changes in the concept of a legal state as stipulated in Article 1 paragraph (3) of the 1945 Constitution of the Republic of Indonesia which has implications for the principle of legality implicit in Article 1 paragraph (1) of the Criminal Code (WvS), where there has been a shift of unlawful behavior from the unlawful nature of the formal law to the unlawful nature of the material law.

If previously the law in Indonesia is absolute sourced to the written law (written law), then since the inclusion of the phrase "the State of Indonesia is a legal state" nofrills word "rechtsstaat" in Article 1 paragraph (3) NRI 1945 Constitution, then it means that Indonesian law other than sourced to the written law (written law) is also sourced to the unwritten law (laws that live in society).

Reconstruction of the value compiled by the author, namely: the legal principle of a flexible, progressive and resfonsive modern legal state. Thus, the principle of legality in the Pancasila legal state is the principle of legality which is a combination of the principle of legal legality that prioritizes the value of legal certainty and the principle of material legality that recognizes the living law in society, namely the application of pluralistic religious and customary law in fulfilling the values of justice and benefit based on Pancasila justice values. The reconsideration of the proposed value, namely: "The principle of Indonesian legality follows the law which comes from written law (law) and unwritten law (living law in society) based on Pancasila justice values". Thus, any legal product under the Constitution must conform and be interpreted in accordance with the mandate of the constitution as stipulated in Article 1 paragraph (3) of the 1945 Constitution of the Republic of Indonesia. This means that in the positive legal system of Indonesia must be in one unity of the legal system integral, one color one pattern in upholding the law which is based on Pancasila based justice values. 
The principle of legality adopted in Indonesia has its own distinctive characteristic that is not the same and owned by other nations, because it is sourced and rooted from the culture and values that exist and live in the community of Indonesia, which is based on religious law for each adherents and pluralistic customary law. The reconstruction of the legal principle of legality that can be advanced is: "Legal principle originating from written law (law) and unwritten law (pluralistic religious law and custom law) based on Pancasila justice value".

\section{CONCLUSION}

After the third amendment of the 1945 Constitution, the term rechtsstaat is no longer included, but only states: "The state of Indonesia is a state of law". In a theoretical way, the conception of the legal state embraced by Indo-nesia is not only from the formal dimension but also in the material sense or commonly used in the terminology of the welfare state or welfare state. Therefore, the goal to be achieved by the state of Indonesia is the realization of a just and prosperous society both spiritual and material based on Pancasila, so it is also called a legal state that has independent characteristics, namely the legal state based on Pancasila. The removal of the word rechtsstaat in Article 1 paragraph (3) of the 1945 Constitution of the Republic of Indonesia, it is increasingly asserted, that the conception of the legal state that is embraced by Indonesia is the concept of a legal state material or the concept of a state law in the broad sense, meaning not rely solely legal certainty but also prioritizes legal certainty for obtaining justice which also opens the opportunity for application in the court (punishment) of unwritten law or law living in society (religious law and customary law). The interpretation of Article 1 Paragraph (3) of the 1945 Constitution after the amendment, that Indonesia as a constitutional state derived from written law and unwritten law (living and growing law in a society consisting of religious law and customary law) the value of Pancasila justice;

Implementation of law enforcement in criminal justice so far tend to be done with rigid procedural.
After the enactment of the 1945 Constitution (after amendment) in which there has been a change in the concept of an Indonesian legal state in which the implicit principle of legality is implied by the occurrence of acknowledgment of unwritten law (living law in society, namely religious law and customary law). Such conditions have implications for all sets of Indonesian laws under the 1945 Constitution of the State of the Republic of Indonesia whose position as the highest source of law after Pancasila as grundnorm. The implications of the amendment also apply to all the provisions relating to the principle of legality in the Indonesian penal code law whose position under the 1945 Constitution of the Republic of Indonesia in accordance with the provisions of Article 7 of Law Number 12 Year 2011 which implies: Article 5 paragraph (1) and Article 50 paragraph (1) of Law Number 48 Year 2009; Article 8 paragraph (4) of Law Number 16 Year 2004; Article 1 paragraph (1) and paragraph (2) and Article 103 of the Criminal Code; Decision of the Constitutional Court Number: 013 / PUU-I / 2003 and Number: 003 / PUU-IV / 2006; and National Criminal Laws of 2015. All official regulations as a positive law concerning the legality principle in Indonesia must adapt and be guided by the legality principle within the legal state as stipulated in Article 1 paragraph (3) of the 1945 Constitution of the Republic of Indonesia; b. Reconstruction of the compiled values, ie the legal principle of a flexible, progressive and responsive modern legal state. Thus, the principle of legality in the Pancasila legal state is the principle of legality that is a combination of the principle of legal legality that prioritizes the value of legal certainty and the principle of material legality that recognizes the living law in society, namely the application of pluralistic religious and customary law in fulfilling the values of justice and benefit based on Pancasila justice values. The principle of legality embraced in Indonesia has its own distinctive characteristic that is not the same and owned by other nations, because it is sourced and rooted from the culture and values that exist and live in development in the people of Indonesia, which is based on religious law for each adherents and pluralistic customary law. 
The Government and Parliament need to amend Article 1 paragraph (1) and Article 1 paragraph (2) of the Criminal Code as harmonization or adjustment with the provisions of Article 1 paragraph (3) of the 1945 Constitution of the Republic of Indonesia; The legislature (the legislature and the government) should respect and adhere to the basic norms of Pancasila consistently in establishing / regulating legislation; It is expected that the regulatory body (DPR and the government) should always adhere to principles and be careful in formulating the articles by considering the legal values that grow and live in the community (customary and religious law); To all parties engaged in the field of law without exception to work in accordance with the profession and the field of science by not making statements or opinions that are not based on legitimate juridical norms and must legawa familiarize themselves to surrender the affairs to the people who are experts and have science of the affairs and always improve their knowledge and professionalism respectively. For legal practitioners in implementing Indonesian legislation, it is strived to be accompanied by exploring the values of living and developing in the people of Indonesia, which are values that come from religious law and customary law.

\section{BIBLIOGRAPHY}

I Made Wirartha. 2006. Metodologi Penetilian Sosial Ekonomi, Andi Offset, Yogyakarta.

Moeljatno. 1987. Azas-Azas Hukum Pidana, Bina Aksara, Jakarta.

Moh. Mahfud MD. 2006. Membangun Politik Hukum Menegakkan Konstitusi, Pustaka LP3ES, Jakarta.

, 2010.Perdebatan Hukum Tata Negara Pasca Amandemen Konstitusi, Raja Grafindo Persada, Jakarta.

Pieter Mahmud Marzuki. 2006. Penelitian Hukum, Cetakan Kedua, Prenada Media Group, Jakarta.

Satjipto Rahardjo. 2004. Demokrasi Butuh Dukungan Hukum Progresif, Kompas, Jakarta. 1979. Hukum dan Perubahan Sosial, Alumni, Bandung,

Soedikno Mertokoesoemo. 2007. Penemuan Hukum Sebuah Pengantar, Universitas Atma Jaya, Yogyakarta.

Sugiyono. 2009. Metode Penelitian Bisnis (Pendekatan Kuantitatif, Kualitatif dan R\&D), Alfabeta, Bandung.

Wirjono Prodjodikoro. 2003. Asas-Asas Hukum Pidana Di Indonesia, Refika Aditama, Bandung.

Bambang Sutiyoso, Implementasi Gugatan Legal Standing dan Class Action Dalam Praktik Peradilan Di Indonesia, Jurnal Hukum lus Quia lustum, Vol. 26 No. 11, Mei 2004, FH UII, Yogyakarta, 2004.

Moh. Mahfud MD, Politik Hukum Menuju Pembangunan Sistem Hukum Nasional, Makalah Seminar :"Arah Pembangunan Hukum Menurut UUD 1945 Hasil Amandemen", BPHN, Jakarta, 29-31 Mei 2006.

Ninil Eva Yustina, Perbuatan Melawan Hukum Materiil (Materiel Wederrechtelijkeheid) Dalam Tindak Pidana Korupsi Pada Praktek Peradilan Indonesia Pasca Putusan Mahkamah Konstitusi, Artikel (Rangkuman Tesis pada Program Pasca-sarjana IImu Hukum Konsentrasi Hukum Pidana Universitas Merdeka Malang, 21 Februari 2009. 
Wahyu Nugrono, Menyusun Undang-Undang Yang Responsif dan Partisipatif Berdasarkan Cita Hukum Pancasila, Jurnal Legislasi Indonesia, Vol. 10 No. 3, Edisi September 2013, Direktorat Jenderal Peraturan Perundang-undangan Kementerian Hukum dan HAM RI, Jakarta, 2013.

Yanis Maladi, Eksistensi Hukum Adat Dalam Konstitusi Negara Pasca Amandemen, Jurnal Mimbar Hukum, Vol. 22 No. 3, Edisi Oktober 2010, Fakultas Hukum UGM, Yogyakarta, 2010.

Yohanes Usfunan, Kebebasan Berpendapat Di Indonesia, (Disertasi), Dalam Meraih gelar Doktor pada Program Pascasarjana UNAIR, Surabaya, 1998.

http://rezarizkyfarza.blogspot.co.id/2013/05/penafsiran-hukum.html 